\title{
PENGARUH DOSIS KAPUR DOLOMIT TERHADAP PERTUMBUHAN DAN HASIL TANAMAN KELAPA SAWIT (Elaeis guineensis Jacq) TM 15 PADA ULTISOL DI KABUPATEN BUNGO
}

\author{
M. Bahrul Rozi ${ }^{1}$, Budi Prastia ${ }^{2}$ \\ ${ }^{1,2}$ Program Studi Agroteknologi Fakultas Pertanian \\ Universitas Muara Bungo
}

Naskah Diterima Januari 201, disetujui Maret 2019

\begin{abstract}
ABSTRAK
Penelitian ini dilaksanakan di Desa Rantau Keloyang Kecamatan Pelepat Kabupaten Bungo, yaitu pada ketinggian tempat $\pm 125 \mathrm{~m}$ di atas permukaan laut, pada Ultisol dengan $\mathrm{pH}$ 5,0. Percobaan ini dilaksanakan dari Bulan September 2017 s/d April 2018. Adapun tujuan dari penelitian ini ialah untuk mengetahui pengaruh dosis kapur dolomit terhadap hasil tanaman kelapa sawit (Elaeis guineenses Jacq) TM 15 pada Ultisol di Kabupaten Bungo.

Rancangan yang digunakan adalah Rancangan Acak Kelompok (RAK) dengan 5 taraf perlakuan kapur dolomit yaitu : D0 ( Tanpa kapur dolomit), D1

( Dosis 0,5 kg /pokok), D2 (Dosis 1,0 kg/pokok), D3 (Dosis 1,5 kg /pokok) dan D4 (Dosis 2,0 $\mathrm{kg} /$ pokok). Data hasil pengamatan terakhir dianalisis dengan sidik ragam. Apabila terdapat pengaruh nyata maka dilanjutkan dengan uji Duncan New's Multiple Range Test (DNMRT) pada taraf $5 \%$.

Parameter Yang Diamati : yaitu Jumlah Pelepah (Buah), Jumlah Tandan (Buah), Berat Buah Per janjang $(\mathrm{Kg})$ dan Lingkar Buah $(\mathrm{cm})$. Dari hasil penelitian menunjukkan bahwa pemberian kapur dolomit berpengaruh nyata terhadap Jumlah Pelepah (Buah), Jumlah Tandan (Buah), Berat Buah Per janjang (Kg) dan Lingkar Buah (cm). Pemberian kapur dolomit dengan dosis $1,0 \mathrm{~kg} /$ pokok merupakan hasil terbaik terhadap pertumbuhan dan produksi tanaman kelapa sawit.
\end{abstract}

\section{Kata kunci : Dolomit, kelapa sawit dan produksi.}

\section{PENDAHULUAN}

Indonesia merupakan negara penghasil kelapa sawit (Elaeis guineensis Jacq) terbesar di dunia. Kebutuhan buah kelapa sawit (Elaeis guineensis Jacq) meningkat tajam seiring dengan meningkatnya kebutuhan CPO dunia. Bagi Indonesia tanaman kelapa sawit (Elaeis guineensis Jacq) memiliki arti penting dalam pembangunan perkebunan nasional. Selain mampu menciptakan kesempatan kerja yang mengarah kepada kesejahteraan masyarakat dan sebagai sumber devisa negara. Bahkan dalam kondisi krisis ekonomi sekalipun terbukti mampu survive dan tetap tumbuh apalagi dikelola dengan baik dan benar (Fauzi $d k k ., 2014$ ).

Produktivitas tanaman kelapa sawit di Indonesia juga dipengaruhi oleh beberapa faktor antara lain yaitu, faktor lingkungan, faktor genetik, dan teknik budidaya. Faktor lingkungan (enforce) yang mempengaruhi produktivitas kelapa sawit meliputi faktor abiotik (curah hujan, hari hujan, tanah, topografi) dan faktor biotik (gulma, hama, jumlah populasi tanaman/ha). Faktor genetik (innate) meliputi varietas bibit yang 
digunakan dan umur tanaman kelapa sawit. Faktor teknik budidaya (induce) meliputi pemupukan, konservasi tanah, air, pengendalian gulma, pengendalian hama, dan pengendalian penyakit tanaman, serta kegiatan pemeliharaan lainnya. Faktorfaktor tersebut saling berhubungan dan mempengaruhi satu sama lain (Pahan 2007).

Kabupaten Bungo dengan luas areal tanaman kelapa sawit mencapai $31.594 \mathrm{Ha}$, sedangkan untuk produksi CPO sebesar 102.113 ton dengan produktivitas $3.232 \mathrm{~kg} / \mathrm{ha} /$ tahun (Statistik Perkebunan Indonesia, 2015). Produktivitas CPO tanaman kelapa sawit di Kabupeten Bungo masih sangat rendah bila dibandingkan dengan produktivitas CPO di Malaysia yaitu sebesar $3900 \mathrm{~kg} / \mathrm{ha} /$ tahun, sedangkan untuk produktivitas TBS di Kabupaten Bungo hampir sama dengan seluruh wilayah yang ada di Indonesia yaitu berkisar 2-3 ton/ha, hasil ini masih jauh jika dibandingkan dengan produktivitas TBS di Malaysia yang mencapai 12 ton/ha (Saputra, 2014). Penyebab rendahnya produktivitas diantaranya mutu bibit dan teknik budidaya yang belum optimal. Teknik budidaya yang perlu mendapat perhatian yaitu pemberian kapur dolomit untuk meningkatkan kesuburan tanah.

Hampir sebagian besar dari tanaman kelapa sawit dapat dijadikan sebagai bahan baku industri baik industri pangan maupun industri non pangan. Untuk keperluan industri pangan daging buah kelapa sawit dapat dijadikan sebagai minyak goreng, mentega, biscuit sedangkan industri non pangan dapat dimanfaatkan untuk penghasil biodiesel untuk keperluan bahan bakar minyak dan pembangkit listrik. Cangkang dan sabut kelapa juga dapat digunakan sebagai pengganti solar untuk pembangkit listrik tenaga uap. Sedangkan limbah TKKS sebagai pupuk organik, pulp kertas, batang untuk perabot dan partikel board serta pelepah bisa di jadikan sebagai pakan ternak (Pardamean, 2011).

Kapur dolomit berperan dalam memperbaiki sifat fisik, kimia dan biologi tanah, karena secara langsung dapat menyuplai unsur hara makro berupa $\mathrm{Ca}$ dan $\mathrm{Mg}$, serta kondisi $\mathrm{pH}$ tanah dapat meningkat sehingga memberikan kondisi lingkungan yang lebih baik bagi perkembangan dan aktivitas mikroorganisme tanah (Setiawan, 2010).

Kapur dolomit sebagai bahan penyedia kalsium, pemberian kapur dolomit tidak hanya untuk menambah $\mathrm{Ca}$, namun juga berfungsi sebagai penyedia unsur hara lainnya, di samping itu kapur dolomit juga dapat digunakan untuk meniadakan keracunan $\mathrm{Fe}$ dan $\mathrm{Mn}$. Tersedianya $\mathrm{Ca}$ dan unsur lainnya menyebabkan pertumbuhan generatif menjadi lebih baik, sehingga mengakibatkan hasil panen menjadi lebih tinggi (Handoyo, dkk., 2015).

Berdasarkan hasil penelitian Sudrajat dan Fitria (2015) bahwa pemberian dosis pupuk dolomit dapat memberikan pengaruh nyata terhadap tinggi tanaman, lingkaran batang, jumlah daun dan kandungan klorofil daun pada tanaman kelapa sawit. Menurut Ardian (2017), bahwa dosis kapur dolomit untuk tanaman kelapa sawit yang berumur 15- 25 tahun yaitu $0,75 \mathrm{~kg} /$ pokok/aplikasi.

\section{METODOLOGI PENELITIAN}

$\begin{array}{ccc} & \text { Penelitian ini } & \text { dilaksanakan di Desa } \\ \text { Rantau Keloyang Kecamatan Pelepat }\end{array}$ Kabupaten Bungo, yaitu pada ketinggian tempat $\pm 125 \mathrm{~m}$ di atas permukaan laut, pada Ultisol dengan $\mathrm{pH}$ 5,0. Percobaan ini dilaksanakan dari tanggal 30 September 2017 s/d 28 April 2018.

Bahan-bahan yang digunakan dalam penelitian ini adalah tanaman kelapa sawit varietas tenera TM 15, kapur dolomit, pupuk buatan (Urea, SP 36 dan $\mathrm{KCl}$ ), herbisida 
Round-up, Ally 20 WDG, Sportox dan air bersih. Adapun alat-alat yang digunakan dalam penelitian ini yaitu cangkul, ember, galon, krapsek sprayer, gelas ukur, meteran, timbangan, tangga, papan merk, gerobak, dodos, eggrek, toyak, tali rapia, cutter, alat dokumentasi serta alat tulis dan alat penunjang lainya.

Rancangan yang digunakan adalah Rancangan Acak Kelompok (RAK) dengan 5 taraf perlakuan yaitu:

D0 : Tanpa kapur dolomit

D1 : Dosis $0,5 \mathrm{~kg} /$ pokok

D2 : Dosis $1,0 \mathrm{~kg} /$ pokok

D3 : Dosis $1,5 \mathrm{~kg} /$ pokok

D4 : Dosis 2,0 kg /pokok

Penelitian ini dilaksanakan dalam beberapa tahap yaitu :

\section{Persiapan Lahan}

Penyiapan lahan pada prinsipnya membebaskan lahan dari tumbuhan pengganggu atau komponen lain seperti contohnya gulma, pengendalian gulma pada gawangan dan piringan dikendalikan dengan menggunakan herbisida Roundup + Ally 20 WDG untuk gulma anak kayu dan ilalang dengan dosis 100 cc/liter air. Roundup yang digunakan terlebih dahulu dicampur Ally 20 WDG 30 g per liter Roundup. Untuk gulma jenis lain dikendalikan dengan herbisida sportok dengan dosis $150 \mathrm{cc} /$ liter air.

Agar lebih efektik dalam merawat kelapa sawit,perlu di buatkan piringan di sekitar batang tanaman dengan diameter tertentu. Piringan berfungsi sebagai tempat menaburkan pupuk sehingga dapat diserap oleh tanaman secara maksimal.

Gulma yang tumbuh dipiringan tanaman kelapa sawit dikendalikan secara manual dengan menggunakan cangkul dengan lebar priringan 2,0 meter dari pokok. Rotasi pembersihan gulma dilakukan 2 bulan sekali.

\section{Persiapan Tanaman Percobaan}

Sebelum melakukan penelitian tanaman percobaan harus di bersihkan terlebih dahulu dari gangguan gulma dan tumbuhan pengganggu lainnya yang tumbuh dipokok tanaman baik secara manual maupun secara mekanis, setelah bersih seluruh tanaman percobaan di pruning dengan sistem songgo dua kemudian diberikan pupuk sesuai dosis yang telah ditentukan.

\section{Pemasangan Label}

Pemasangan label pada unit percobaan dilakukan secara random dengan sistem acak untuk tiap kelompok, selanjutnya dilakukan pengacakan pada kelompok yang lain, setelah dilakukan pengacakan kemudian label di pasang di setiap pokok tanaman kelapa sawit yang sudah terpilih secara acak.

\section{Pemberian Perlakuan Kapur Dolomit}

Pemberian perlakuan sesuai dengan dosis yang diteliti yaitu mulai dari tanpa kapur dolomit hingga dosis 2,0 kg/pokok. Sebelum di lakukan pengapuran piringan harus di bersihkan terlebih dahulu dari gulma dan tumbuhan pengganggu lainnya, setelah bersih maka diberikan kapur dolomit dengan cara menabur secara merata pada piringan mulai dari pangkal pokok hingga berjarak 2,0 meter dari pokok tanaman.

\section{Pemberian Pupuk Tunggal}

Seminggu setelah dilakukan pengapuran minggu selanjutnya maka diberikan pupuk tunggal berupa pupuk SP 36 dengan dosis 1,5 kg/pokok. Seminggu kemudian menyusul pupuk tunggal Urea dan $\mathrm{KCl}$ dengan dosis yang sama yaitu masingmasing $2 \mathrm{~kg} /$ pokok pupuk di berikan secara merata mulai dari pangkal pokok hingga berjarak 2,0 meter dari pokok tanaman.

\section{Pemeliharaan}

Pemeliharan meliputi pembersihan piringan, gawangan, dan pasar pikul dari gangguan gulma dan tumbuhan pengganggu lainnya, pengendalian gulma dilakukan 
dengan interval 2 bulan sekali baik secara manual maupun secara mekanis.

\section{Pengamatan}

Pengamatan sebelum perlakuan, yaitu yang diamati sebelum perlakuan antara lain kondisi lahan, kondisi tanaman baik dari segi pertumbuhan tanaman maupun dari hasil produksi tanaman.

Pengamatan sesudah perlakuan, yang diamati sesudah perlakuan yaitu melihat pengaruh kapur dolomit yang diberikan ke setiap tanaman perlakuan terhadap parameter yang diamati.

\section{Panen}

Penen dilakukan dengan rotasi 15 hari sekali. Kriteria umum yang banyak dipakai adalah berdasarkan jumlah brondolan, yaitu tanaman dengan umur kurang dari 10 tahun, jumlah brondolan sebanyak 10 butir dan tanaman dengan umur 15 tahun, jumlah brondolan sebanyak 15-20 butir. Namun, secara praktis digunakan kriteria yang umum yaitu pada setiap $1 \mathrm{~kg}$ tandan buah segar (TBS) terdapat dua brondolan Fauzi dkk., (2014).

Sedangkan parameter yang diamati dalam penelitian ini adalah : Jumlah Pelepah (Buah), Jumlah Tandan (Buah), Berat Buah Per Janjang $(\mathrm{kg})$, dan Lingkar Buah $(\mathrm{cm})$. Untuk melihat pengaruh perlakuan kapur dolomit terhadap parameter yang diamati, data dari hasil pengamatan di himpun selanjutnya diuji dengan analisis ragam,apabila hasil analisis menujukkan pengaruh nyata maka dilanjutkan dengan uji Duncan New Multiple Range Test (DNMRT) pada taraf $5 \%$ (Steel and Torrie, 1994).

\section{HASIL DAN PEMBAHASAN}

\section{Pengamatan Pendahuluan}

Sebelum perlakuan seluruh tanaman sampel di lakukan pengamatan awal dengan rataan masing-masing parameter sesuai Tabel 1.
Tabel 1. Rataan Jumlah Pelepah, Jumlah Tandan, Berat Buah Per Janjang Dan Lingkar Buah.

\begin{tabular}{|c|c|c|c|c|}
\hline $\begin{array}{c}\text { Perlak } \\
\text { uan }\end{array}$ & $\begin{array}{c}\text { Jumlah } \\
\text { Pelepah } \\
\text { (buah) }\end{array}$ & $\begin{array}{c}\text { Jumlah } \\
\text { Tandan } \\
\text { (buah) }\end{array}$ & $\begin{array}{c}\text { Berat Buah } \\
\text { Per Janjang } \\
(\mathrm{kg})\end{array}$ & $\begin{array}{c}\text { Lingkar } \\
\text { Buah } \\
(\mathrm{cm})\end{array}$ \\
\hline D0 & 40 & 3.75 & 14.65 & 113.70 \\
\hline D1 & 40 & 4.55 & 15.75 & 114.75 \\
\hline D2 & 40 & 5.10 & 15.90 & 114.85 \\
\hline D3 & 40 & 4.20 & 14.90 & 113.95 \\
\hline D4 & 40 & 5.35 & 16.55 & 115.80 \\
\hline Rataan & 40 & 4.59 & 15.55 & 114.61 \\
\hline
\end{tabular}

\section{Jumlah Pelepah (Buah)}

Hasil analisis ragam menunjukan bahwa pemberian kapur dolomit berpengaruh nyata terhadap pertambahan jumlah pelepah (buah) tanaman kelapa sawit. Rataan pertambahan jumlah pelepah dan pengaruh dosis kapur dolomit dapat dilihat pada Tabel 2.

Tabel 2. Rataan Jumlah Pelepah Tanaman Kelapa Sawit Akibat Pemberian Dosis Kapur Dolomit

\begin{tabular}{lc}
\hline Perlakuan & $\begin{array}{c}\text { Rataan Jumlah } \\
\text { Pelepah (Buah) }\end{array}$ \\
\hline D0 & $7.66 \mathrm{~b}$ \\
D1 & $9.55 \mathrm{a}$ \\
D2 & $9.66 \mathrm{a}$ \\
D3 & $10.22 \mathrm{a}$ \\
D4 & $9.89 \mathrm{a}$ \\
\hline \multicolumn{2}{c}{}
\end{tabular}

Keterangan : Angka-angka yang ikuti oleh huruf kecil yang berbeda pada kolom yang sama menunjukkan berbada nyata menurut uji DNMRT pada taraf $5 \%$

Tabel 2. menunjukkan bahwa pemberian perlakuan dosis kapur dolomit berpengaruh nyata terhadap jumlah pelepah tanaman kelapa sawit. Hasil penelitian menunjukkan bahwa perlakuan DO (tanpa kapur dolomit) berdeda dengan pemberian perlakuan dosis kapur dolomit ( D1, D2, D3 dan D4). 
Perlakuan (D1, D2, D3 dan D4) tidak menunjukkan perbedaan terhadap pertambahan jumlah pelepah. Perlakuan terbaik adalah perlakuan D1 dengan jumlah pelepah 9.55 buah. Hal ini dikarenakan dosis kapur dolomit yang diberikan lebih sedikit bila dibandingkan dengan (D2, D3 dan D4). Perlakuan D0 merupakan perlakuan dengan jumlah pelepah yang paling sedikit bila dibandingkan dengan yang lainnya yaitu 7.66 buah. Rendahnya jumlah yang dihasilkan pada perlakuan D0 dikarenakan unsur hara yang dapat diserap oleh tanaman sedikit bila dibandingkan dengan perlakuan yang lainnya. Perlakuan D1 merupakan merupakan dosis optimum terhadap jumlah pelepah. Perlakuan (D2, D3 dan D4) terjadi peningkatan hasil yang menurun sehingga tidak efesien (konsumsi mewah). Kelebihan pupuk dapat menyebabkan konsumsi berlebih/mewah dan dapat menggangu metabolisme tanaman. Pelakuan D1 dengan dosis $0.5 \mathrm{~kg} /$ pokok telah mampu memacu pertambahan jumlah pelepah tanaman kelapa sawit. Jumlah pelepah meningkat dengan meningkatnya pemberian dosis kapur dolomit hal ini dikarenakan unsur $\mathrm{P}$ yang terkandung dalam kapur dolomit dapat meningkatkan pertumbuhan vegetatif pada tanaman kelapa sawit.

Menurut Handoyo, $d k k$, (2015), bahwa unsur $\mathrm{P}$ yang terdapat dalam kapur dolomit dapat merangsang pertumbuhan akar tanaman sebagai bahan untuk pembentukan protein dan selain itu unsur $\mathrm{P}$ juga berfungsi sebagai pengangkut energi.

Menurut Sutedjo (2010), bahwa salah satu unsur hara yang berperan untuk pertambahan jumlah pelepah pada tanaman kelapa sawit yaitu Nitrogen, disini nitrogen berperan dalam pembentukan organ vegetatif. Organ vegetatif yang terbentuk yaitu jumlah pelepah pada tanaman kelapa sawit.

\section{Jumlah Tandan (Buah)}

Hasil analisis ragam menunjukkan bahwa pemberian kapur dolomit berpengaruh nyata terhadap produksi jumlah tandan per pokok. Rataan produksi jumlah tandan tanaman kelapa sawit per pokok dapat dilihat pada Tabel 3 .

Tabel 3. Rataan Jumlah Tandan Tanaman Kelapa Sawit Akibat Pemberian Dosis Kapur Dolomit

\begin{tabular}{lc}
\hline Perlakuan & $\begin{array}{c}\text { Rataan Jumlah } \\
\text { Tandan (Buah) }\end{array}$ \\
\hline D0 & $4.88 \mathrm{c}$ \\
D1 & $6.55 \mathrm{ab}$ \\
D2 & $7.11 \mathrm{ab}$ \\
D3 & $7.33 \mathrm{a}$ \\
D4 & $6.33 \mathrm{~b}$ \\
\hline
\end{tabular}

$\mathrm{KK}=3,73 \%$

Keterangan : Angka-angka yang ikuti oleh huruf kecil yang berbeda pada kolom yang sama menunjukkan berbada nyata menurut uji DNMRT pada taraf $5 \%$

Tabel 3. menunjukkan bahwa pemberian perlakuan dosis kapur dolomit berpengaruh nyata terhadap jumlah tandan tanaman kelapa sawit. Hasil penelitian menunjukkan bahwa perlakuan DO (tanpa kapur dolomit) berbeda dengan perlakuan pemberian dosis kapur dolomit (D1, D2, D3 dan D4). Perlakuan D1 merupakan perlakuan terbaik dengan jumlah tandan yaitu 6.55 buah.

Perlakuan D4 berbeda dengan perlakuan (D0, D1,D2 dan D3). Pelakuan (D1, D2 dan D3) tidak menunjukkan perbedaan terhadap jumlah tandan. Perlakuan terbaik adalah perlakuan D1 dengan jumlah tandan yaitu 6.55 buah.

Hal ini dikarenakan dosis kapur dolomit yang diberikan lebih sedikit bila dibandingkan dengan perlakuan (D2 dan D3). Menurut Sutedjo (2010), bahwa kelebihan pupuk menyababkan konsumsi berlebih/mewah dan dapat mengganggu metabolisme tanaman. Perlakuan D1 dengan dosis $0.5 \mathrm{~kg} /$ pokok telah mampu memacu 
terbentuknya buah maupun tandan kelapa sawit, dan pada perlakuan D4 terjadi peningkatan hasil yang menurun sehingga tidak efesien (konsumsi mewah) Menurut Trisnawati, et al., (1994) dalam Saijo, (2011), bahwa pemberian kapur dolomit berpengaruh nyata terhadap jumlah buah kelapa sawit pertanaman. Pada proses pelapukan dolomit akan terbentuk asam-asam organik maupun anorganik yang menyebabkan daya larut unsur-unsur lain seperti $\mathrm{P}, \mathrm{K}$ dan $\mathrm{Ca}$ menjadi lebih tinggi sehingga lebih tersedia bagi tanaman. Hal ini akan memberikan pengaruh terhadap jumlah hara yang dapat di absorpsi oleh tanaman. Unsur K mempengaruhi pembentukan buah dan unsur $\mathrm{P}$ berperan pandukung dalam pembentukan buah, proses fotosintesis, metabolisme karbohidrat dan pembentukan protein, karena tersedianya unsur P merupakan jaminan bagi penyusunan karbohidrat dan protein yang disimpan dalam buah.

Banyaknya unsur hara yang diserap dapat dijadikan bahan dasar fotosintesis, dengan pemberian kapur dolomit diharapkan dapat meningkatkan produksi pelepah, jumlah pelepah yang banyak dapat meningkatkan serapan sinar matahari lebih banyak serta mempermudah proses melakukan fotosintesis. Menurut Haryoko (2003) mengatakan bahwa jumlah energi matahari yang ditangkap digunakan untuk proses fotosintesis serta pembentuk asimilat selanjutnya asimilat yang dihasilkan dapat di distribusikan untuk pembentukan buah.

\section{Berat Buah Per Janjang (kg)}

Berdasarkan analisis ragam bahwa pemberian perlakuan dosis kapur dolomit berpengaruh nyata terhadap berat buah per janjang . Rataan berat buah per janjang $(\mathrm{kg})$ tanaman kelapa sawit dan pengaruh pemberian dosis kapur dolomit dapat dilihat pada Tabel 4.
Tabel 4. Rataan Berat Buah Per Janjang Tanaman Kelapa Sawit Akibat Pemberian Dosis Kapur Dolomit

\begin{tabular}{ll}
\hline Perlakuan & $\begin{array}{l}\text { Rataan } \\
\text { Buah } \\
\text { Perjanjang (kg) }\end{array}$ \\
\hline D0 & $14.16 \mathrm{c}$ \\
D1 & $17.50 \mathrm{~b}$ \\
D2 & $21.75 \mathrm{a}$ \\
D3 & $22.49 \mathrm{a}$ \\
D4 & $20.52 \mathrm{a}$ \\
\hline & $\mathrm{KK}=5.43 \%$
\end{tabular}

Keterangan : Angka-angka yang ikuti oleh huruf kecil yang berbeda pada kolom yang sama menunjukkan berbada nyata menurut uji DNMRT pada taraf $5 \%$

Tabel 4. menunjukkan bahwa pemberian perlakuan dosis kapur dolomit berpengaruh nyata terhadap berat buah per janjang tanaman kelapa sawit. Hasil penelitian menunjukkan bahwa perlakuan DO (tanpa kapur dolomit) berbeda dengan pemberian perlakuan dosis kapur dolomit (D1, D2, D3 dan D4). Perlakuan D0 merupakan perlakuan dengan berat buah perjanjang yang paling rendah bila dibandingkan dengan yang lainnya yaitu $14.16 \mathrm{~kg}$. Perlakuan D1 berbeda dengan perlakuan (D0, D2, D3 dan D4).

Perlakuan (D2, D3 dan D4) tidak menunjukkan perbedaan terhadap berat buah per janjang. Perlakuan terbaik adalah perlakuan D2 dengan berat janjang yaitu $21,75 \mathrm{~kg}$. Hal ini dikarenakan dosis kapur dolomit yang diberikan lebih sedikit bila dibandingkan dengan perlakuan (D3 dan D4). Perlakuan D2 dengan dosis 1.0 $\mathrm{kg} /$ pokok telah mampu untuk meningkatkan berat buah per janjang pada tanaman kelapa sawit, kelebihan pupuk menyebabkan konsumsi berlebih/mewah dan dapat mengganggu metabolisme tanaman.

Menurut Soepardi, (1993) dalam Saijo, (2011), bahwa pemberian kapur dolomit sangat berpengaruh nyata terhadap berat buah. Hal ini di duga karena dolomit 
dapat meningkatkan kandungan unsur $\mathrm{N}, \mathrm{P}$, dan $\mathrm{K}$ tersedia di dalam tanah. Peningkatan konsentrasi unsur-unsur tersebut dalam larutan tanah diikuti pula oleh peningkatan serapan unsur $\mathrm{Ca}$ dan $\mathrm{Mg}$ yang ada dalam kapur dolomit oleh tanaman. Sebagian besar unsur N,P, K, Ca, Mg diserap melalui difusi yang berlangsung dari permukaan tanah, mamasuki jaringan tanaman dan menembus selaput sel, terus memasuki perakaran, dan semakin tinggi kepekatan $\mathrm{N}, \mathrm{P}$, dan $\mathrm{K}$ di dalam tanah, semakin memudahkan tanaman menyerapnya.

Menurut Sarief, (2000) dalam Saijo, (2011), bahwa berat buah erat kaitannya dengan ketersediaan unsur $\mathrm{P}$ yang terdapat dalam kapur dolomit, unsur $\mathrm{P}$ yang terdapat dalam kapur dolomit juga sangat berguna dalam pembentukan buah karena dalam proses pembentukan buah diperlukan unsur $P$ yang cukup tersedia, selain unsur $P$ unsur hara $\mathrm{Ca}$ dan $\mathrm{Mg}$ yang terdapat dalam kapur dolomit juga sangat berguna antara lain untuk memperbaiki kesuburan tanah serta untuk meningkatkan produksi tanaman.

\section{Lingkar Buah (cm)}

Hasil analisis ragam menunjukkan bahwa pemberian dosis kapur dolomit berpengaruh nyata terhadap lingkar buah (cm). Rataan lingkar buah tanaman kelapa sawit dapat di lihat pada Tabel 5.

Tabel 5. Rataan Lingkar Buah Tanaman Kelapa Sawit Akibat Pemberian Dosis Kapur Dolomit

\begin{tabular}{cc}
\hline Perlakuan & $\begin{array}{c}\text { Rataan Lingkar } \\
\text { Buah }(\mathbf{c m})\end{array}$ \\
\hline D0 & $114.77 \mathrm{c}$ \\
D1 & $117.44 \mathrm{c}$ \\
D2 & $129.33 \mathrm{~b}$ \\
D3 & $138.11 \mathrm{a}$ \\
D4 & $134.22 \mathrm{ab}$ \\
\hline \multicolumn{3}{c}{} \\
\hline
\end{tabular}

Keterangan : Angka-angka yang ikuti oleh huruf kecil yang berbeda pada kolom yang sama menunjukkan berbada nyata menurut uji DNMRT pada taraf $5 \%$

Tabel 5. menunjukkan bahwa pemberian perlakuan dosis kapur dolomit berpengaruh nyata terhadap lingkar buah tanaman kelapa sawit. Hasil penelitian menunjukkan bahwa perlakuan DO (tanpa kapur dolomit) tidak berbeda dengan perlakuan D1 tetapi berbeda dengan perlakuan (D2, D3 dan D4). Perlakuan D0 merupakan perlakuan dengan lingkar buah yang paling rendah bila dibandingkan dengan yang lainnya. Sedangkan perlakuan (D3 dan D4) tidak menunjukkan perbedaan terhadap lingkar buah. Perlakuan terbaik adalah perlakuan D3 dengan lingkar buah yaitu $138,11 \mathrm{~cm}$. Hal ini dikarenakan dosis kapur dolomit yang diberikan lebih sedikit bila dibandingkan dengan perlakuan D4. Perlakuan D3 dengan dosis $1.5 \mathrm{~kg} /$ pokok telah mampu untuk memacu pertambahan lingkar buah pada tanaman kelapa sawit.

Menurut Trisnawati, et al., (1994) dalam Saijo, (2011), bahwa pengaruh kapur dolomit sangat nyata terhadap diameter buah. Hal ini di duga karena pemberian kapur dolomit dapat memperbaiki struktur tanah dan daya menahan air sehingga lebih mampu menahan air dan memudahkan penyerapan unsur hara oleh akar tanaman. Tanaman mengabsorbsi unsur hara dalam bentuk ion $\mathrm{P}$ dan kation $\mathrm{P}$ diabsorbsi dalam bentuk $\mathrm{H}_{2} \mathrm{PO}_{4}{ }^{-}$dan $\mathrm{H}_{2} \mathrm{PO}_{4}^{-2}$. Kapur dolomit dapat meningkatkan $\mathrm{pH}$ tanah dan penambahan unsur hara $\mathrm{Ca}$ dan $\mathrm{Mg}$ pada tanah sehingga kandungan unsur hara yang terdapat didalam bokashi yang diberikan semakin tersedia dan mudah diserap oleh tanaman, dan tersedianya hara yang diabsorbsi dalam bentuk kation antara lain tergantung pada bahan organik.

Selain unsur hara $\mathrm{Ca}$ dan $\mathrm{Mg}$ yang terkandung didalam kapur dolomit terdapat juga unsur $\mathrm{P}$ yang terkandung di dalamnya, unsur $\mathrm{P}$ sangat berpengaruh langsung pada pertumbuhan vegetatif dan generatif pada 
suatu tanaman terutama untuk pembesaran buah. Menurut Agustina, (1990) dalam Saijo, (2011), menyatakan bahwa unsur P diperlukan tanaman dalam pemindahan energi yang berguna pula dalam pembentukan membran sel sehingga pembentukan buah semakin besar, jika ukuran buah semakin besar tentu diameter buah juga semakin besar.

\section{KESIMPULAN}

Berdasarkan hasil penelitian yang telah dilakukan, maka dapat disimpulkan sebagai berikut :

1. Pemberian kapur dolomit berpengaruh nyata terhadap semua parameter yang diamati antara lain yaitu : jumlah pelepah (buah), jumlah tandan (buah), berat buah per janjang $(\mathrm{kg})$ dan lingkar buah $(\mathrm{cm})$.

2. Pemberian kapur dolomit dengan dosis $1.0 \mathrm{~kg} /$ pokok merupakan hasil yang terbaik terhadap pertumbuhan dan produksi tanaman kelapa sawit TM 15.

\section{DAFTAR PUSTAKA}

Ardian,I.F.2017.Dosis dolomit. https://www.scribd.com/doc/254426 250/Dosis-dolomit. diakses 21

Febuari 2018.

Fauzi, Y., Yustina E. Widystuti., Iman Satyawibawa dan Rudi H. Paeru. 2014. Kelapa Sawit. Penerbit Penebar Swadaya. Jakarta.

Handoyo, Y, R., Sigit Suparjono dan Irwan Sadiman. 2015. Pengaruh Dosis Dolomit dan Macam Bahan Organik Terhadap Hasil dan Kualitas Benih Kedelai (Glycine max (L.) Merr.) Prodi Agroteknologin Universitas Jember, Jurnal Berkala Ilmiah Pertanian.
Haryoko, W, 2003, Pertumbuhan dan Hasil Tanaman Bengkuang dengan Pemberian Kompos. Jurnal Akademika Kopertis x, Vol 7 No. 1.

Lakitan, Benyamin. 2013. Dasar-dasar Fisiologi Tumbuhan. Rajawali Press. Jakarta.

Mangoensoekarjo dan Semangun. 2008 Manajemen Agrobisnis Kelapa Sawit. UGM Press. Yogyakarta

Nurhakim, Y.I. 2014. Perkebunan Kelapa Sawit Cepat Panen. Penerbit Infra Group. Jakarta.

Nyakpa, M.Y., A.M Lubis., M.A. Pulung., A.G. Amrah., Go Ban Hong dan Nurhayati Hakim. 1988. Kesuburan Tanah. Penebit Universitas Lampung.

Pahan, I. 2007. Panduan Lengkap Kelapa Sawit. Penerbit Penebar Swadaya. Jakarta.

Pardamean, M. 2011. Sukses Membuka Kebun dan Pabrik Kelapa Sawit. Penerbit Penebar Swadaya. Jakarta.

Saijo, 2011. Pengaruh Pemberian Kapur Dolomit Terhadap Hasil Tomat Pada Tanah Gambut. Fakultas Pertanian dan Kehutan Universitas Muhammadiyah Palangkaraya.

Saputra, W. 2014. Tata Kelola Industri Kelapa Sawit dan Pembiayaan Kasus Indonesia VS Malaysia. Diskusi OMS ICW, Bakoel Coffe 17 Januari 2014. Jakarta.

Sastrosayono,S. 2003. Budidaya Kelapa Sawit. Agromedia Pustaka. Jakarta. 
JURNAL SAINS AGRO

Volume 4, Nomor 1, April 2019

Setiawan, B. S. 2010. Membuat Pupuk Kandang Cepat. Penebar Swadaya. Jakarta.

Statistik Perkebunan Indoseia. 2015. Kelapa Sawit (Palm Oil). Direktorat Jendral Perkebuan Jakarta.

Steel and Torrie, 1994. Prinsip dan Prosedur. Statistika Suatu Pendekatan Metrik. Penerbit PT Gramedia Pustaka Utama. Jakarta.

Sudrajat dan Fitria. 2015. Optimalisasi Dosis Pupuk Dolomit Pada Tanaman Kelapa Sawit (Elaeis guineensis Jacq) Jurnal Agrovigor No.8 Vol.1. Depertemen Agronomi dan
E-ISSN : 2580-0744

http://ojs.umb-bungo.ac.id/index.php/saingro/index

Hortikultura. Institut Pertanian Bogor.

Sutedjo, M. 2010. Pupuk Dan Cara Pemupukan. Rineka Cipta. Jakarta.

Tim Bina Karya Tani. 2009. Pedoman Bertanam Kelapa Sawit. Penerbit C.V. Yrama Widya.Bandung Jawa Barat.

Tim Pengembangan Materi LPP. 2004. Seri Budidaya Tanaman Kelapa Sawit. Lembaga Pendidikan Perkebunan. Yokyakarta.

Vidanarko. 2011. Buku Pintar Kelapa Sawit. Agromedia Pustaka. Jakarta 